\title{
CORRUPTIVE INCOMINGS LAUNDERING IN THE MEDICAL SPHERE
}

DOI: 10.36740/WLek202105138

\author{
Oleg M. Reznik, Olha S. Bondarenko, Maryna S. Utkina, Nadiia S. Horobets \\ SUMY STATE UNIVERSITY, SUMY, UKRAINE
}

\begin{abstract}
The aim: Characteristic of corruptive incomings laundering in the medical sphere and research of components for counteraction to this phenomenon.

Materials and methods: Some methods were used to ensure the completeness and complexity of scientific research: dialectical, formal, legal, epistemological, and systemstructural methods.

Conclusions: It was concluded that corruptive incomings laundering in the medical sphere is becoming commonplace. New ways, means, and schemes for the commission of this crime are appearing. The authors analyze the main methods for corruptive incomings laundering in the medical sphere: during the purchase of medicines and medical equipment, during the procurements of medical preparations and medical equipment, building restoration and renovation, where health care facilities are located, price-fixing and gifting of chief medical officers. A comprehensive system of organizational, legal, and economic measures must be formed that will provide effective counteraction to the corruptive incomings laundering in the medical sphere.
\end{abstract}

KEY WORDS: corruption, money laundering, Covid-19, medical field, counteraction

Wiad Lek. 2021;74(5):1250-1255

\section{INTRODUCTION}

Ukraine has been pursuing a consistent and phased state policy focused on counteracting the negative practices in the economy, management, and law for several years. In particular, the money and corruptive incomings laundering. For this purpose, there is political willpower, a certain normative legal framework, the experience of control-supervisory and law-enforcement activity, experience of the preventive measures' organization [1, p. 111]. However, the status of counteraction to the money laundering is fundamentally ineffective, as the facts of policy failure are obscured by idiosyncratic assessments of "effectiveness", poorly related to the principles of policy development $[2$, p. 74]. After all, the analysis of statistical data confirms the abundance of this phenomenon. For example, budget losses due to money laundering in 2020 amounted to UAH 4.8 billion. Such a high level of damage is due to the emergence of a new direction in money laundering - medical corruption, which has increased especially due to the pandemic caused by COVID-19. The imposition of nationwide quarantine in Ukraine and the urgent need for public procurement of medical preparations, protective gear, and medical equipment have prompted the movement of corrupt officials interests in this sphere. Besides, in 2020, the most significant increase in expenditures on pensions and the state program of medical guarantees - by UAH 29.7 billion and UAH 15.7 billion, respectively. Besides, the Anti-COVID-19 Fund was established. From the beginning, the Fund pledged UAH 64.7 billion. Considering the changes adopted by the laws of Ukraine and the decisions of the Cabinet of Ministers of Ukraine, the volume of the fund amounted to 66 billion hryvnias. As of July 24, 2020, the Government has distributed UAH 66 billion of funds from the Anti-COVID-19 Fund in priority spheres. Thus, the amount of funds allocated from the Fund reached the amount of budget allocation approved in the state budget for 2020 for the Fund. The COVID-19 package in the draft budget-2021 contains a conjunction of medical services within the program of medical guarantees and is a measure to respond to the COVID-19 epidemic. Its volume is 15.8 billion hryvnias [3]. At the same time, given the disease incidence negative dynamics, the state can re-create a special Anti-COVID-19 Fund in 2021. Also, medical reform has led to the accumulation of funds directly in hospitals, which is also an opportunity to appropriate funds. All these factors have led to the prevalence of money laundering in the medical sphere.

\section{THE AIM}

The article aims to characterize the corruptive incomings laundering in the medical sphere and research of components for counteraction to this phenomenon.

\section{MATERIALS AND METHODS}

The study of the characteristics of corruptive incomings laundering in the medical sphere and the study of the components for counteracting this phenomenon are carried out using dialectical, formal, legal, epistemological and system-structural methods. The essence of the concepts of "laundering" is defined using a dialectical method. The 
formal legal method was used to disclose the content and interpretation of the provisions of some regulations of the current legislation of Ukraine on combating the legalization of criminal proceeds. The epistemological method of the research made it possible to find out the peculiarities of certain methods of corruptive incomings laundering in the medical sphere. The statistical method was used to determine the amount of damage caused to the state by money laundering. The system-structural method provided research both from the point of view of legal and economic sciences.

\section{REVIEW AND DISCUSSION}

\section{THE ESSENCE OF MONEY LAUNDERING}

The term "money laundering" was first used in the 1980's in the United States for incomings from the drug trade and means the process of converting illegally obtained money into legal money. Many definitions of this concept have been proposed in the sciences society. The US Presidential Commission on Organized Crime in 1984 used the following formulation: "Money laundering is a process by which the existence of illegal origin or illegal use of income is disguised, disguised in such a way as to give them the appearance of legally obtained" [4, p. 103]. The legislator understands this act as effecting financial transactions and other deals involving money or other property known to be proceeds from socially dangerous criminal offenses prior to legalization (laundering) of incomes, and committing acts aimed at covering up the illegal origin of such money or other property or their ownership, the rights to such money or property, their origin, location, transfer, as well as obtaining, holding or use of money or other property known to be proceeds from socially dangerous criminal offenses prior to legalization (laundering) of incomes [5].

This crime is characterized by high social danger, as it is a kind of stage of criminal activity and is often associated with corruption, contributes to its formation, financing, and progress. In the conditions of public relations constant development, ways of commission of the analyzed crime and forms of its expression quickly develop. These phenomena negatively affect the investigation process, require the use of many resources and special narrow knowledge. As Michael Levi emphasizes, money laundering is a socially harmful phenomenon also because it undermines the democratic control and legitimacy of the state itself [6, p. 314].

\section{COOPERATION IN THE SPHERE OF COMBATING CORRUPTIVE INCOMINGS LAUNDERING}

International cooperation in the sphere of combating corruptive incomings laundering is developing quite dynamically. This is largely because the prerequisites for international legal regulation were laid by multilateral and bilateral international treaties on mutual legal assistance in criminal matters in the 50s of the twentieth century. Acts directly regulating activities to combat money laundering appeared in the late twentieth - early twenty-first century: the UN Convention against Illicit Traffic in Narcotic Drugs and Psychotropic Substances, 1988; International Convention for the Suppression of the Financing of Terrorism 1999; UN Convention against Transnational Organized Crime, 2000 , etc. The current status of international cooperation in the field of combating money laundering is characterized by impressive quantitative indicators. There are currently 9 universal conventions; 14 UN Security Council resolutions; 40 bilateral agreements with the participation of the Russian Federation; 15 intergovernmental agreements; 49 international standards. International legal obligations, formulated in the universal international conventions of the United Nations, are developed in regional international treaties and recommendations of international organizations. International law establishes not only the principles, standards, and rules of interstate cooperation in combating and preventing money laundering, but also provides an institutional system that ensures the interaction of states in the analyzed area [7, p. 461].

Financial action task force (FATF) has a special place among international organizations that pay significant attention to corruption as a source of funds accumulation that can participate in the legalization (laundering) of criminal proceeds. FATF is an independent international organization, which includes: Argentina, Australia, Austria, Belgium, Brazil, Canada, Denmark, Finland, France, Germany, Greece, Hong Kong (China), Iceland, Ireland, Spain, Italy, Luxembourg, Mexico, Netherlands, New Zealand, Norway, Portugal, Russia, Singapore, South Africa, Sweden, Switzerland, Turkey, Great Britain, USA, Japan. Also, two international organizations - the European Commission and the Gulf Co-operation Council are also members of the FATF. The FATF is a global regulatory authority for money laundering and terrorist financing. The intergovernmental body sets international standards aimed at preventing these illegal activities and the damage they cause to society. As a policy-making body, the FATF works to create the necessary political will to implement national legislative and regulatory reforms in these areas.

Today, more than 200 countries and jurisdictions are required to comply. The FATF has developed the FATF Recommendations or FATF Standards, which provide a coordinated global response to the prevention of organized crime, corruption, and terrorism. They help the authorities to find the money of criminals. The FATF is reviewing money laundering methods and is constantly tightening its standards to address new risks, such as the regulation of virtual assets, which are spreading as cryptocurrencies become popular. The FATF monitors countries to ensure that they fully and effectively implement FATF Standards, and holds countries accountable for non-compliance [8]. The history of cooperation between Ukraine and the FATF began with Ukraine's independence and shows Ukraine's insufficient use of tools to combat corruption and legalize (launder) criminal proceeds (money laundering) owned by this international organization. The high level of shadowing of the economy (shadow gross domestic product (GDP) was about 70\%), monopolization 
and criminalization of the economy, underdevelopment of the financial sector were characteristic of Ukraine after the dissolution of the Soviet Union. The implementation of the FATF recommendations has been extremely slow and unsystematic. That is why on September 1,2001, Ukraine was included in the "sanctioned party list" of the FATF, which characterized it as one that does not take measures to combat legalization (laundering) of criminal proceeds [9]. Adding to the " sanctioned party list" became a kind of brief-stimulus therapy for Ukrainian society and led to certain reforms. On February 14, 2003, the FATF decided to lift countermeasures against Ukraine. It considered this issue at its session in Paris, where the Ukrainian delegation was also presented. Currently, many organizational, legal, economic, and social measures are being introduced in Ukraine aimed at combating the legalization of criminal proceeds. However, not all of them are effective and need some improvement.

As to responsibility for enforcing anti-money laundering legislation in European Union primarily falls with national competent authorities designated by Member States when transposing Anti-money laundering Directives. The nature of these authorities varies across Member States. Enforcement of Anti-money laundering rules may imply, therefore, cooperation and exchange of relevant information among authorities with different mandates and characteristics, namely, so-called financial intelligence units and financial (mostly prudential) supervisors [10]. Regarding the organization of international cooperation in the field of prevention and counteraction corruptive incomings laundering in the medical sphere, it is carried out on the principle of mutuality by international treaties of Ukraine, approved by the Verkhovna Rada of Ukraine, other regulations. The Security Service of Ukraine with the participation of the Ministry of Foreign Affairs of Ukraine carries out international cooperation in submitting proposals to UN Security Council committees and foreign states regarding the inclusion (exclusion) of individuals or legal entities and organizations in relevant sanctions lists and consideration of foreign states' requests for inclusion (exclusion) to (from) the List of persons. When submitting proposals to foreign states regarding the inclusion of individuals, legal entities and organizations in the relevant sanctions lists, the Security Service of Ukraine and the Ministry of Foreign Affairs of Ukraine shall provide as detailed information as possible on such persons or organizations, including information necessary to identify individuals. and information confirming that individuals, legal entities, and organizations meet the criteria set out in UN Security Council resolutions for inclusion in the relevant lists. The Ministry of Foreign Affairs of Ukraine is developing procedures for submitting a request for expulsion of persons and organizations included in the relevant sanctions lists of the UN Security Council and publishes them on its official website.

The Ministry of Foreign Affairs of Ukraine cooperates internationally as to applying to the UN Security Council committees for permission to access assets (notification of intent to grant access to assets) related to terrorism and its financing, proliferation and financing of absolute dead calm weapon. Ensuring international cooperation in the field of prevention and counteraction also relies on: 1) the Ministry of Justice of Ukraine - on the execution of judicial decisions relating to the confiscation of proceeds from crime; 2) the Prosecutor General's Office of Ukraine, the National Anti-Corruption Bureau of Ukraine - to commit procedural actions in criminal proceedings for legalization (laundering) of proceeds from crime, or terrorist financing or financing the proliferation of weapons of mass destruction [11].

\section{MAIN WAYS OF CORRUPTIVE INCOMINGS LAUNDERING IN THE MEDICAL SPHERE}

Among the ways to commit corruptive incomings laundering in the medical sphere, it is proposed to analyze the most common. It is not uncommon for a multimillion-dollar tender for the renovation or overhaul of a health care facility to be won by an organization that is not engaged in construction or repair work, has no production facilities or employees. At the same time, the accounts of this company receive budget funds, part of which is appropriated, and the rest following the sub-contract agreement, is transferred to existing companies that are directly engaged in construction or repair work. Portion of the proceeds remaining with the winner of the tender is used as a "payoff" for those who contributed to the budget order [12].

Due to the financial investigation conducted by the State Financial Monitoring Service of Ukraine, a scheme of money laundering received by officials as an improper advantage was identified. After the results of the victory in the competitive procurement of the Ministry of Health of Ukraine, a contract was signed with enterprise B for the procurement of medicine remedies and medical equipment, after which funds for UAH 291.5 million were transferred to the account of this enterprise. Instead, no actual supply of medicines took place within the time specified in the contract. The proceeds were converted and transferred to non-resident company A (US \$ 26.2 million and EUR 0.24 million) and non-resident company B (EUR 0.1 million). Subsequently, non-resident company A transferred funds to the group of non-resident companies as payment for construction and electrical equipment, electronics, credit, including to the account of non-resident company $\mathrm{C}$, in the total amount of USD 3.6 million. According to the financial intelligence unit of a foreign country, funds totaling 0.25 million euros were transferred from non-resident companies $\mathrm{B}$ and $\mathrm{C}$ to the accounts of Ukrainian citizens (citizen $C$ and citizen D) opened in a Greek banking institution. After that, part of the funds received of 0.13 million euros, these individuals used to purchase real estate in Greece. Given that citizen $\mathrm{C}$ and citizen $\mathrm{D}$ are officials of a state-owned enterprise of Ukraine, the funds for 0.25 million euros may be associated with the receipt of illegal benefits. Criminal proceedings are currently underway on this fact [13, p. 35].

Besides, money laundering is also possible when purchasing medical preparations and medical equipment through the 
Prozzoro system. For example, legally operating enterprises engaged in the production or sale of medical preparations and medical equipment can be used to place "dirty" funds. Such an enterprise receives "dirty" cash as a payment from the health care facilities for the products sold. The following implementations of this method of placing funds are possible: 1) recognition of funds as receipts from sales of medical preparations and medical equipment that are not actually produced or sold (not provided);2) sale of medical preparations and medical equipment based on the prices that significantly (several times) exceed the cost of their production (purchase), i.e. price-fixing [14]. Such a money laundering scheme is extremely dangerous, as the poor quality of medical preparations and medical equipment can lead to unpredictable consequences: injury or even life of patients.

The COVID-19 pandemic has led to a sharp rise in prices for certain pharmaceutical drugs and medical equipment. Such rapid growth has become a new direction in the corruptive incomings laundering in the medical sphere, as an involved mechanism for goods price discovery, constant changes in market conditions to determine the real price of acquired assets have become the basis for manipulation and abuse. After all, procurement prices can be artificially overvaulted, and the difference is shared between the chief medical officers of health care facilities and the heads of enterprises that win public procurement for the supply of medical preparations and medical equipment.

Money laundering in the medical sphere also takes place in Ukraine by providing various gifts to chief physicians, and very often to their relatives or proxies. Such gifts are exceedingly difficult to detect, this is also facilitated by the lack of control over sources of income in the purchase of valuables and services $[15$, p. 64$]$.

\section{COMPONENTS AGAINST MONEY LAUNDERING FROM THE MEDICAL CORRUPTION}

Development and implementation of effective, comprehensive state economic, financial and legal policy in the interests against money laundering and corruption, including the state system of regulation of financial and economic activities, monetary policy in the interests of combating money laundering and corruption. It is proposed to analyze the main components that will provide effective counteraction to money laundering from medical corruption.

The first component involves improving the regulatory framework to increase the effectiveness of national interests and the economic security of the state. For the purpose, on December 6, 2019, Ukraine adopted the Law of Ukraine "On Prevention and Counteraction to Legalization (Laundering) of Proceeds from Crime, Terrorist Financing, and Financing of the Proliferation of Weapons of Mass Destruction". This law adopts the Ukrainian legislation on prevention and counteraction to money laundering to the norms of the fourth EU Directive 2015/849 and EU Regulation 2015/847, FATF standards. After all, by the Association Agreement between Ukraine and the European Union, the European Atomic Energy
Community and their Member States, it is necessary to ensure the implementation of relevant international standards, including FATF standards, as well as standards equivalent to those adopted by the Union. On 20 May 2015, the European Parliament and the Council of the European Union adopted Directive (EU) 2015/849 on the harmonization of European Union legislation with International Standards against Money Laundering and Terrorist Financing and the Proliferation of Weapons of Mass Destruction, adopted by the FATF in February 2012. prevention of the use of the financial system for money laundering and terrorist financing" and approved Regulation (EU) 2015/847 "On information accompanying money transfers". In this regard to comply with the legal system of Ukraine in the field of combating money laundering and terrorist financing and proliferation of weapons of mass destruction, taking into account the criteria set by the European Union (EU) to the countries intending to join, national legislation required changes. The provisions of Directive (EU) 2015/849 and Regulation (EU) № $2015 / 847$ are implemented in the legislation of Ukraine, in particular in the Law of Ukraine "On Prevention and Counteraction to Legalization (Laundering) of Proceeds from Crime, Financing of Terrorism and Financing of Proliferation of Weapons of Mass Destruction", which is based on the recommendations of the FATF [16].

The second component involves the management of threats and risks of criminalization and shadowing of the economy in the medical sphere. Currently, the threatening indicators of the shadow economy and corruption in Ukraine necessitate the consolidation of efforts of representatives of state and local authorities, science and the public, the judiciary and law enforcement system to strengthen the effectiveness of combating these destructive phenomena $[17$, p. 48]. The spread of the shadow economy is organically linked to the process of money laundering, as it serves, firstly, as the "customer" of unaccounted funds, and secondly, as the largest "producer" of illicit proceeds. Illegal income-generating activities, in particular the commission of crimes, do not fall within the scope of economic laws and principles. At the same time, the capital obtained in this way is spent on the purchase of new drugs, introduced into the legal economy, thus causing an imbalance (rising prices, inflation, etc.) [17, p. 64]. Effective areas of de-shadowing with the use of economic tools are elimination of tax minimization schemes and de-shadowing of wages $[17, \mathrm{p} .40]$.

The third component is effective and professional anti-corruption expertise of economic projects and management decisions for such risks and threats. Anti-corruption examination is the activity of specialists (experts) in connection with the identification and description of corruption-causing factors related to current legal acts and their projects; development of recommendations aimed at eliminating or limiting the effects of such factors [18, p. 6]. The procedure for conducting such an examination is determined by the Law of Ukraine "On Prevention of Corruption" the entities authorized to implement it 
(Ministry of Justice of Ukraine, relevant parliamentary committee, National Agency for Prevention of Corruption, public), the procedure for publishing such examination and more. It should be noted that in practice, the detection of a corruption-causing factor sometimes becomes either a difficult task or completely unprofitable, because you can just bribe an official to a positive conclusion of such an examination. Thus, there is a circle of despair: corruption generates even more corruption, because to exercise their rights in the state legally becomes unprofitable or simply impossible [19, p. 745].

The fourth component involves the spread of anti-crime and anti-corruption morality in society, intensification of media activities aimed at educating high morals and dignity, the involvement of the active part of the population in the system of counteraction, including through the formation of public control. All the above are attributes of the rule of law and developed civil society. Implementing this component is the most difficult because it is necessary to change not only the legal or economic approaches but also the mentality of the people, which, of course, requires huge costs and constant targeted influence. The fifth component is to increase the efficiency of control, law enforcement, and other law enforcement agencies and courts in the field of economics, including compliance with the adapted recommendations of international organizations. To implement it, it is necessary to increase the level of professionalism not only of law enforcement officers but also of other bodies performing control and supervisory functions. It is necessary to train personnel in higher educational institutions; employees of these bodies must have special knowledge in the field of civil, tax, financial, banking, criminal law [20, p. 32]. The sixth component provides for the broad involvement of the scientific and expert community and scientific developments in the field of economic management, the creation of effective applied brain centers, domestic consulting structures, situational centers and centers of strategic management.

\section{CONCLUSIONS}

In concluding, we would like to note that corruptive incomings laundering in the medical sphere is becoming commonplace. New ways means, and schemes for the commission of this crime are appearing. The authors analyzed the main methods for corruptive incomings laundering in the medical sphere: during the purchase of medicines and medical equipment, during the procurements of medical preparations and medical equipment, building restoration and renovation, where health care facilities are located, price-fixing and gifting of chief medical officers. It is important that a comprehensive system of organizational, legal and economic measures has been formed to ensure effective counteraction to the legalization of corrupt income in the medical field. A comprehensive system of organizational, legal, and economic measures must be formed that will provide effective counteraction to the corruptive incomings laundering in the medical sphere.

\section{REFERENCES}

1. Selivanov A. Protivodeystviye legalizatsii prestupnykh dokhodov i korruptsii: finansovo-ekonomicheskiye aspekty [Countering to Legalization Criminal Profits and Corruption: Financial and Economic Aspects]. Bulletin of Financial University. 2014; 6:110-117. (in Russian).

2. Ronald F. Pol. Anti-money laundering: The world's least effective policy experiment? Together, we can fix it. Policy Design and Practice. 2020; 3(1): 73-94. D0l:10.1080/25741292.2020.1725366.

3. Government portal. https://www.kmu.gov.ua/.

4. Kashpur L. M. Protydiya lehalizatsiyi dokhodiv, oderzhanykh zlochynnym shlyakhom [Counteraction of Incomes Legalization which are llegally Received]. Investments: practice and experience. 2018; 3:103-106. (in Ukrainian).

5. Criminal code of Ukraine №. № 2341-III. dated April 05, 2001. https:// zakon.rada.gov.ua/laws/show/2341-14\#Text

6. Levi M. Evaluating the Control of Money Laundering and its Underlying Offences: the Search for Meaningful Data. Asian Journal of Criminology. 2020; 15:301-320. https://doi.org/10.1007/s11417-020-09319-y.

7. Khabriyeva T. Protivodeystviye legalizatsii (otmyvaniyu) dokhodov, poluchennykh prestupnym putem, i finansirovaniyu terrorizma v usloviyakh tsifrovizatsii ekonomiki: strategicheskiye zadachi i pravovyye resheniya [Counteraction to the legalization (laundering) of proceeds from crime and the financing of terrorism in the context of the digitization of economy: strategic objectives and legal solutions]. Russian Journal of Criminology. 2018; vol. 12, no. 4:459-467. D01: 10.17150/2500-4255.2018.12(4).459-67. (in Russian).

8. The official website of The Financial Action Task Force. http://www. fatf-gafi.org.

9. Official site of the National Institute for Strategic Studies. https://niss. gov.ua/en.

10. Deslandes J., Dias C. and Magnus M. Economic Governance Support Unit (EGOV). Directorate-General for Internal Policy 614.496. 2019. https:// www.europarl.europa.eu/.

11. On prevention and counteraction to legalization (laundering) of proceeds from crime, financing of terrorism and financing of proliferation of weapons of mass destruction: Law of Ukraine of December 6, 2019 № № 361-IX. https://zakon.rada.gov.ua/laws/show/361-20?lang=en\#Text.

12. Batantseva A. Vidmyvannya dokhodiv otrymanykh vid koruptsiynoyi diyal'nosti u sferi okhorony zdorov'ya [Money laundering received from corrupt activities in the field of health care]. State finance. 2020. Available from: https:// ibfor.com/index.php?newsid=3633. (in Ukrainian).

13. Chernyavsky S. Finansovi rozsliduvannya u sferi borot'by zlehalizatsiyeyu kryminal'nykh dokhodiv v Ukrayini [Financial investigations in the field of combating the legalization of criminal income in Ukraine]. Kyiv: Nat. acad. internal Affairs. 2017; 164. (in Ukrainian).

14. Official website of the State Audit Office of Ukraine. http://www.dkrs. gov.ua/.

15. Baranov R. Suchasni skhemy vidmyvannya zlochynnykh koshtiv u sviti ta v Ukrayini [Modern schemes of money laundering in the world and in Ukraine]. Mechanisms of public management. 2015; 7-8:62-69. (in Ukrainian).

16. Draft Law on Prevention and Counteraction to Legalization (Laundering) of Proceeds from Crime, Financing of Terrorism and Financing of the Proliferation of Weapons of Mass Destruction. http://w1.c1.rada.gov. ua/pls/zweb2/webproc4_1?pf3511=66949.

17. Cherney V.V. Chernyavsky V.I., Shakun V.I. Tin'ova ekonomika: svitovi tendentsiyi ta ukrayins'ki realiyi [Shadow economy: world tendencies and Ukrainian realities: materials of interdepartmental scientific practice]. conf. (Kyiv, June 23, 2017). Kyiv: Nat. acad. internal Affairs. 2017; 448. (in Ukrainian). 
18. Lopashenko N. A. Antykoruptsiyna ekspertyza normatyvnopravovykh aktiv ta yikh proektiv (federal'nyy ta rehional'nyy aspekty) [Anticorruption expertise of normative legal acts and their projects (federal and regional aspects)]: monograph. Moscow: Yuritinform, 2011; 248. (In Russian)

19. Bondarenko 0. S., Pakhomov V. V., Lukianenko Yu. V. Corrupt lobbying in Ukraine: essence, determinants and countermeasures. Russian Journal of Criminology, 2018;12(5):738-47. D0I: 10.17150/25004255.2018.12(5). (In Russian).

20. Fazilov F.M. Reduprezhdeniye legalizatsii dokhodov, poluchennykh ot prestupnoy deyatel'nosti [Prevention of legalization of revenue from criminal activities]. Bulletin of Science and Education. 2019; 12:30-33. (In Russian)

The article was carried out within the framework of project № 0120 U100474 "Developing of methods of interaction of law enforcement agencies of Ukraine on counteraction to legalization of criminal measures".

\section{ORCID and contributionship:}

Oleg M. Reznik: 0000-0003-4569-8863 ${ }^{E, D}$

Olha S. Bondarenko: 0000-0002-2288-1393 ${ }^{B, C}$

Maryna S. Utkina: 0000-0002-3801-3742 ${ }^{A, B}$

Nadiia S. Horobets: 0000-0002-0282-2775 ${ }^{F}$

\section{Conflict of interest:}

The Authors declare no conflict of interest.

\section{CORRESPONDING AUTHOR} Maryna S. Utkina

Sumy State University

2 Rimsky-Korsakov St., 40000 Sumy, Ukraine

tel: +380995213642

e-mail:m.utkina@yur.sumdu.edu.ua

Received: 29.11 .2020

Accepted: 29.04.2021

A - Work concept and design, B - Data collection and analysis, C - Responsibility for statistical analysis, D-Writing the article, $\mathbf{E}$-Critical review, $\mathbf{F}$ - Final approval of the article 